\title{
Study of as-synthesized and calcined hydrocalumites as possible antacid agents
}

\author{
CARLOS F LINARES*, FREDDY OCANTO, PABLO BRETTO and MARICELA MONSALVE \\ Unidad de Síntesis de Materiales y Metales de Transición, Facultad de Ciencias y Tecnología, \\ Departamento de Química, Universidad de Carabobo, Valencia, Edo. Carabobo, Apartado Postal 3336, Venezuela
}

MS received 1 April 2013; revised 22 June 2013

\begin{abstract}
A hydrocalumite-type solid was synthesized by the homogeneous co-precipitation method by using $\mathrm{Ca}$ and $\mathrm{Al}$ nitrate solutions in a basic medium (NaOH). This solid was calcined at 700 and $900{ }^{\circ} \mathrm{C}$, respectively. Then, solids were characterized by $X$-ray diffraction, FT-IR spectroscopy and BET surface area measurements. Finally, these solids were tested as antacids by using a synthetic gastric juice. Results showed that calcined samples were able to neutralize the synthetic gastric juice in more extension as an as-synthesized hydrocalumite; however, the last solid showed better conditions as a potential antacid.
\end{abstract}

Keywords. Hydrocalumite; calcination; antacid; basicity; characterization.

\section{Introduction}

Hydrocalumites and hydrotalcites are a close family of layered double hydroxides. While, hydrotalcites-like materials can be often synthesized by using different cations of (II) and (III) compositions, hydrocalumites show $\mathrm{Ca}^{2+}$ and $\mathrm{Al}^{3+}$ having a typically very narrow composition in the hydroxide layers. Both structures are based on positive brucite-like layers alternating with anions and water molecules (Rousselot et al 2002).

Synthetic hydrocalumite-type $\left[\mathrm{Ca}_{2} \mathrm{Al}(\mathrm{OH})_{6}\right] \mathrm{NO}_{3} \cdot m \mathrm{H}_{2} \mathrm{O}$ is made up of octahedral $\mathrm{Ca}$ and $\mathrm{Al}$ hydroxides which share edges to form bidimensional layers. $\mathrm{Ca}$ and $\mathrm{Al}$ octahedra are accommodated in the layers in an orderly manner, while in the hydrotalcite-type structures, the sheets contain randomly arranged metal hydroxides components (López-Salinas et al 1996).

Hydrocalumite shows a marked effect in the basic properties, when it is calcined at different temperatures. Thus, for example, hydrocalumite calcined at $1073 \mathrm{~K}$ shows $90 \%$ of strong basic sites, while these basic sites are absent in hydrocalumites calcined at 573-673 K (López-Salinas et al 1996). These differences in the basic properties of hydrocalumite have permitted to be used as basic catalysts in the isomerization of 1-butene reaction (Rousselot et al 2002), biodiesel production (Campos et al 2009) or aldol condensation reactions (Cota et al 2010).

On the other hand, hyperacidity is defined as an abnormal increment of $\mathrm{HCl}$ in the stomach. Hyperacidity should be controlled to avoid several diseases such as

\footnotetext{
*Author for correspondence (clinares@uc.edu.ve)
}

peptic ulcers, gastroesophageal reflux or stomach cancer (Beers and Berkow 1999). Usually, antacids are used for controlling the $\mathrm{pH}$ in the stomach. They could act as neutralizing of stomach acidity and maintaining an adequate $\mathrm{pH}$ in the stomach. Normally, such antacids can be formulated as soluble or no-soluble basic salts $\left(\mathrm{NaHCO}_{3}\right.$ or $\left.\mathrm{CaCO}_{3}\right)$, basic hydroxides such as $\mathrm{Mg}(\mathrm{OH})_{2}$ or $\mathrm{Al}(\mathrm{OH})_{3}$ or mixed basic oxides, such as calcined Al-Mg hydrotalcites (Beers and Berkow 1999). All of them have advantages and disadvantages which allow their use according to the patient's pathology.

Hydrotalcites are very popular as antacids because they can maintain the stomach's $\mathrm{pH}$ between 3 and 5 avoiding an abrupt increase in the stomach's $\mathrm{pH}$ 'rebound effect'. The rebound effect is characterized by an abrupt increase in $\mathrm{pH}$.

Therefore, taking into the account the excellent hydrotalcites properties as antacids, it is plausible that hydrocalumite could present a similar behaviour due to its structure and basic properties are also comparable.

The aim of this work is to synthesize, characterize and calcine at different temperatures $\mathrm{Ca} / \mathrm{Al}$ hydrocalumitetype solids for evaluating their basic properties in vitro as antacid. Results are compared to those obtained with a commercial antacid based on hydrotalcite as active agent.

\section{Experimental}

\subsection{Synthesis of hydrocalumite (HC)}

Hydrocalumite was synthesized by the co-precipitation method previously reported by López-Salinas et al (1996). A $\mathrm{Ca}-\mathrm{Al}$ solution was prepared dissolving $\mathrm{Al}\left(\mathrm{NO}_{3}\right)_{3}$. 
$9 \mathrm{H}_{2} \mathrm{O}(11.90 \mathrm{~g})$ and $\mathrm{Ca}\left(\mathrm{NO}_{3}\right)_{2} \cdot 4 \mathrm{H}_{2} \mathrm{O}(14 \mathrm{~g})$ in distilled water $(100 \mathrm{~mL})$. This solution was added dropwise to $25 \mathrm{~mL}$ of a $\mathrm{NaOH}$ solution (6.90 g) and kept under stirring in an inert atmosphere.

The resultant gel was refluxed by using a glycerin bath at $80{ }^{\circ} \mathrm{C}$ for $12 \mathrm{~h}$, constant agitation and controlled $\mathrm{pH}$ ( $\mathrm{pH} \cong 11$ ) under an inert atmosphere.

A white solid was filtered from the mixture, washed up with abundant distilled water and dried at $100{ }^{\circ} \mathrm{C}$ for $18 \mathrm{~h}$.

Then, portions of as-synthesized hydrocalumite (HC) were calcined to 700 (HC 700) and $900{ }^{\circ} \mathrm{C}$ (HC 900), respectively in an air atmosphere for $4 \mathrm{~h}$.

To ascertain the effectiveness of the synthesized and calcined hydrocalumites as antacid, their behaviour was compared to that of a commercial antacid based on hydrotalcites as active agent.

\subsection{Characterization}

Solids were characterized by XRD, BET surface area and FT-IR. XRD studies were conducted using a Phillips PW 3442 diffractometer with a CuK $\alpha$ radiation $(154,060 \AA)$ for crystalline phase detection between 4 and $80^{\circ}(2 \theta)$, and the patterns obtained were compared with JCPDS data files. Physisorption measurements were performed with a Beckman Coulter SA 3100 instrument; BET surface areas were determined by nitrogen adsorption at $-196{ }^{\circ} \mathrm{C}$ with an $\mathrm{Ar} / \mathrm{N}_{2}$ ratio of $70 / 30$. The presence of functional groups and evaluation of purity of solids were achieved by FT-IR; spectra were recorded in a PerkinElmer 283 spectrometer in the $4000-500 \mathrm{~cm}^{-1}$ range. Samples were prepared mixing the solids with $\mathrm{KBr}$ to form a thin pastille.

\subsection{Antacid capacity}

Antacid capacities of as-synthesized and calcined hydrocalumites were evaluated using the methodology previously reported by Rivera et al (1998) and Linares et al (2005). Solids were tested in a synthetic gastric juice ( $\mathrm{HCl}+$ pepsin, $\mathrm{pH} \approx 1 \cdot 5$ ), contacting $50-500 \mathrm{mg}$ of the solids with an aliquot of $10 \mathrm{~mL}$ of the synthetic gastric juice. This dispersed solution was shaken for $1 \mathrm{~h}$ at $37^{\circ} \mathrm{C}$ to simulate rhythmical movements of the stomach. The solution was then filtered and an aliquot of $10 \mathrm{~mL}$ was evaluated using a calibrated $\mathrm{pH}$ meter.

\section{Results and discussion}

\subsection{Characterization of $\mathrm{HC}$ and calcined HC}

The reaction can be followed as:

$$
\begin{aligned}
& 2 \mathrm{Ca}\left(\mathrm{NO}_{3}\right)_{2} 4 \mathrm{H}_{2} \mathrm{O}+\mathrm{Al}\left(\mathrm{NO}_{3}\right)_{3}+6 \mathrm{NaOH} \rightarrow \\
& \quad\left[\mathrm{Ca}_{2} \mathrm{Al}(\mathrm{OH})_{6} \mathrm{NO}_{3}\right] n \mathrm{H}_{2} \mathrm{O}+6 \mathrm{NaNO}_{3}+(17-n) \mathrm{H}_{2} \mathrm{O} .
\end{aligned}
$$

As synthesized (HC) and calcined hydrocalumites (HC 700 and HC 900) were characterized by FT-IR (figure 1).

For $\mathrm{HC}$, band at 1353 correspond to $\mathrm{NO}_{3}$-ion in the interlayer region (Kok et al 2008). While, two bands between 3500 and $3700 \mathrm{~cm}^{-1}$ could be attributed to $\mathrm{OH}^{-}$ groups. The band at $3639 \mathrm{~cm}^{-1}$ corresponds to $\mathrm{O}-\mathrm{H}$ stretching vibrations in structural $\mathrm{Al}-\mathrm{OH}$ groups; while bands at 3485 and $1022 \mathrm{~cm}^{-1}$ can be assigned to $\mathrm{OH}$ groups of $\mathrm{Ca}(\mathrm{OH})_{2}$ present in the hydrocalumite-type material (Palmer et al 2009; Mora el al 2011). Also, $\mathrm{OH}^{-}$ groups corresponding to water molecules placed in the hydrocalumite interlaminar region could be overlapping the other two bands (Campos et al 2009). A band at $1622 \mathrm{~cm}^{-1}$ confirms the physisorbed water presence.

Between 787 and $509 \mathrm{~cm}^{-1}$, Al-O vibrations of the hydrocalumite structure were observed (Domínguez et al 2011). A band at $1380 \mathrm{~cm}^{-1}$ is characteristic of $\mathrm{C}=\mathrm{O}$ stretching of $\mathrm{CO}_{3}^{2-}$ anions adsorbed on the hydrocalumite surface (Domínguez et al 2011).

When the hydrocalumite is calcined (HC 700 and HC 900), FT-IR spectrum of HC changed. According to López-Salinas et al (1996), Vielle et al (2003) and Campos et al (2009), the transformation of hydrocalumite during calcination occurs in three steps: in the first step $\left(100-200^{\circ} \mathrm{C}\right.$ ), the physisorbed water is lost from the hydrocalumite structure. The second $\left(200-300{ }^{\circ} \mathrm{C}\right)$ and third steps (300-800 ${ }^{\circ} \mathrm{C}$ ) correspond to hydroxylation and expulsion of anions. An exact sequence has not been established.

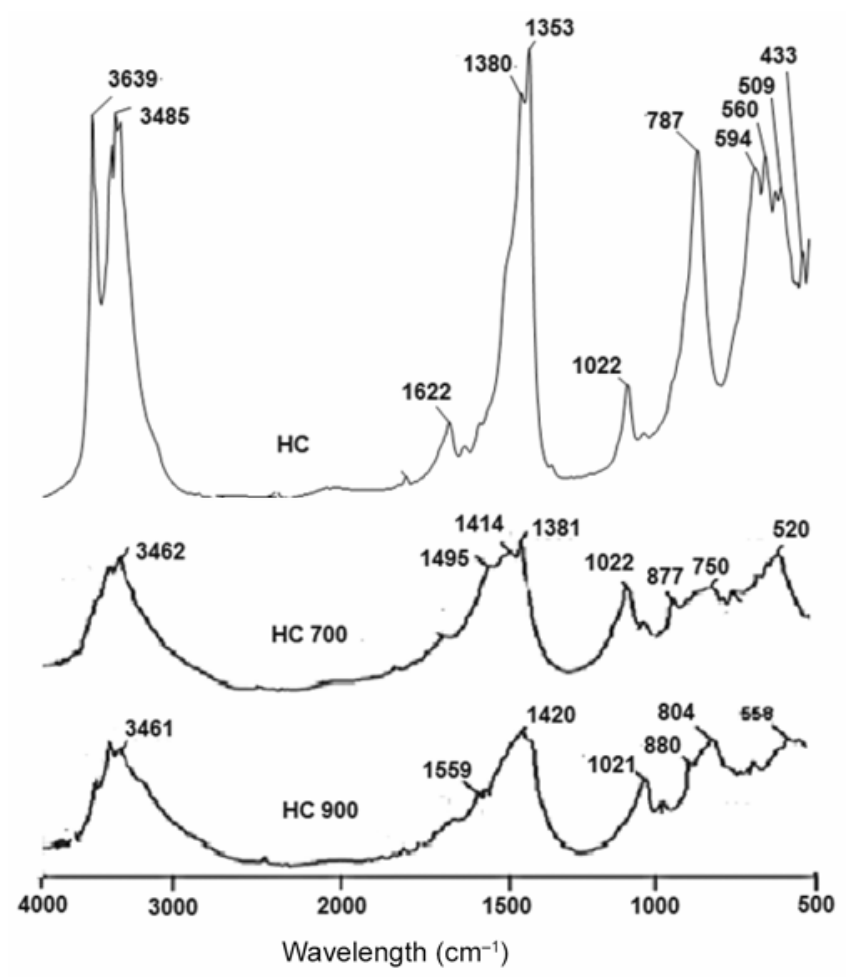

Figure 1. FT-IR spectra of as-synthesized (HC) and calcined hydrocalumite (HC 700 and HC 900). 
For FT-IR spectra of HC 700 and HC 900 samples, the main bands corresponding to nitrate and carbonate anions or physisorbed water diminished or not observed. Then, other wide bands emerged. This could suggest that hydrocalumite structure collapsed, as was mentioned above and other phases could be formed.

A clear identification of hydrocalumite phases could be done by using XRD. Figure 2 shows XRD patterns of HC, HC 700 and HC 900.

Characteristic intense peaks at 10, 20 and 29 degrees ( $2 \theta$ ), and also other less intense bands belonging to $\mathrm{HC}$ (López-Salinas et al 1996) were found in the corresponding sample; moreover, a minor phase of $\mathrm{CaCO}_{3}$ (JCPDS: 85-1108) could also be identified. The basic conditions of synthesis of hydrocalumite, permitted the formation $\mathrm{CaCO}_{3}$ due to absorption of atmospheric $\mathrm{CO}_{2}$.

When hydrocalumite is calcined (700 and $900{ }^{\circ} \mathrm{C}$ ), the structure collapsed and other phases, such as $\mathrm{CaO}$

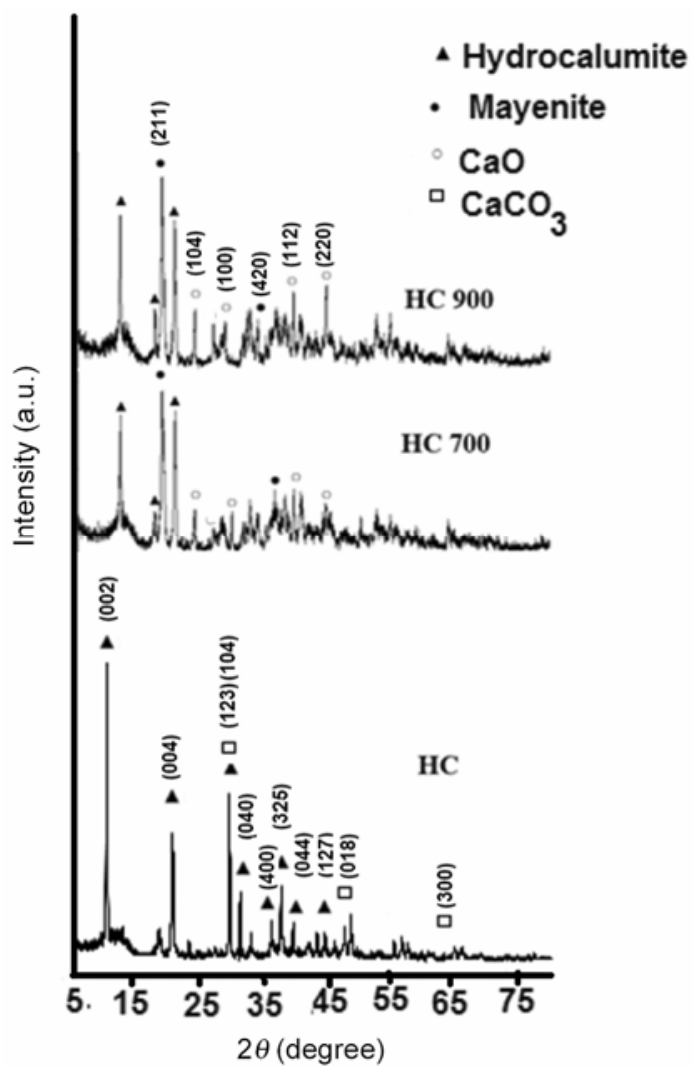

Figure 2. XRD patterns of as-synthesized hydrocalumite (HC) and calcined hydrocalumite (HC 700 and HC 900).

Table 1. BET surface area of as-synthesized and calcined hydrocalumite.

\begin{tabular}{lc}
\hline Solid & BET surface area $\left(\mathrm{m}^{2} / \mathrm{g}\right)$ \\
\hline HC & $40 \cdot 3 \pm 0 \cdot 5$ \\
HC 700 & $13 \cdot 9 \pm 1 \cdot 7$ \\
HC 900 & $10 \cdot 0 \pm 2 \cdot 5$ \\
\hline
\end{tabular}

(JCPDS: 17-0912) or $\mathrm{Ca}_{12} \mathrm{Al}_{14} \mathrm{O}_{33}$, mayenite (JCPDS: 481882) are identified. According to López-Salinas et al (1996), the calcination of $\mathrm{HC}$ at $500{ }^{\circ} \mathrm{C}$ produces $\mathrm{CaO}$, while calcination at higher temperatures (upon $600{ }^{\circ} \mathrm{C}$ ) produces $\mathrm{CaO}$ and $\mathrm{Ca}_{12} \mathrm{Al}_{14} \mathrm{O}_{33}$.

For samples calcined to 700 and $900{ }^{\circ} \mathrm{C}$, hydrocalumite peaks were also identified. Rehydration of the calcined product, the $\mathrm{HC}$, where water and $\mathrm{CO}_{2}$ are absorbed from an air atmosphere could restore HC (Palmer et al 2009).

BET surface area measurements of selected samples were also carried out (table 1). Results showed low BET surface area values. Similar results were reported by López-Salinas et al (1996).

\subsection{Antacid characterization}

Figure 3 shows neutralization capacity as a function of as-synthesized and calcined hydrocalumite masses.

In general, the behaviour of hydrocalumites (assynthesized and calcined samples) is similar, inclusive for the commercial antacid used as reference, $\mathrm{pH}$ increases as the weight of the studied solid is increased.

HC 700 and HC 900 showed the major antacid capacity and their behaviour is quite similar. According to LópezSalinas et al (1996), calcined hydrocalumites show a marked effect in the formation of medium and strong basic sites. Medium basic sites derive from $\mathrm{O}^{2-}$ ions adjacent to the surface $\mathrm{OH}$ group which transform into isolated $\mathrm{O}^{2-}$ ions upon increasing the calcination temperature. The later sites are responsible for the basicity.

In spite of the high neutralization capacity shown for both solids, they cannot be considered as good candidate antacids because the $\mathrm{pH}$ value is violently increased when few amounts of these solids are used. When the $\mathrm{pH}$ is abruptly increased, the 'rebound effect' is emerged (Beer and Berkow 1999).

HC and commercial antacid showed similar activities as antacid. The neutralization capacity of $\mathrm{HC}$ is derived

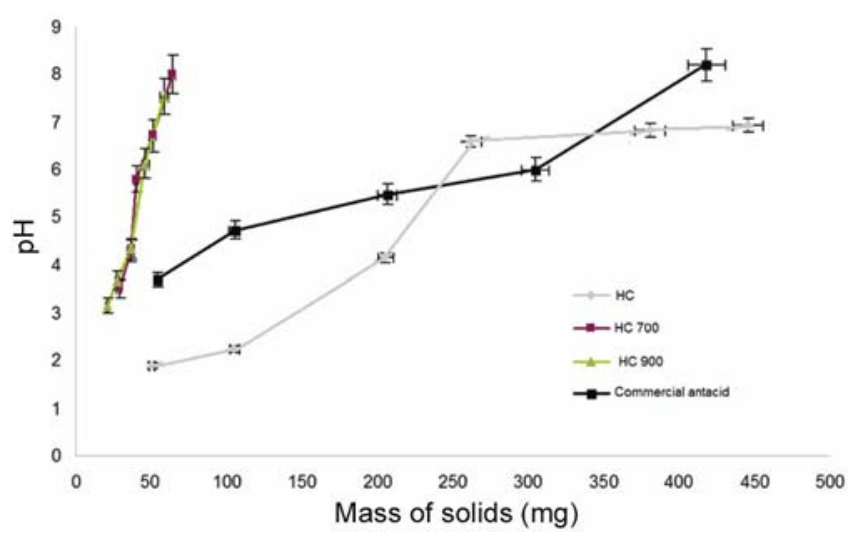

Figure 3. Antacid capacity of as-synthesized, calcined hydrocalumite and a commercial compound as a function of solid masses. 
from surface $\mathrm{OH}$ group and they can be considered as weak basic sites (Malinowski et al 1964). These OH groups can neutralize the free protons in the synthetic gastric juice.

In spite of that HC showed the highest surface area and it is plausible that the behaviour of antacid capacity of assynthesized and calcined hydrocalumite is due to different basic sites showed by the solids as was mentioned above.

The observed similarity between antacid capacity of $\mathrm{HC}$ and the commercial antacid looks very promising since it is known that the active component of this solid is hydrotalcite. This compound is of ample use as antacid due to the ease of $\mathrm{Al}$ and $\mathrm{Mg}$ to form buffer type equilibrium with protons of gastric juice, inhibiting sudden increases of $\mathrm{pH}$ of the gastric juice, avoiding the socalled 'rebound effect' (Fordtran et al 1973), usually observed with sodium carbonate based antacids.

$\mathrm{HC}$ and the commercial compound showed a buffer capacity between 4 and $6 \mathrm{pH}$ units which is considered as an ideal $\mathrm{pH}$ for alleviating symptoms of heartburn.

\section{Conclusions}

It is possible to use as-synthesized hydrocalumites as effective antacid drugs. It was observed that the effectiveness of the hydrocalumite depends on calcination temperature. BET surface area does not seem to be a fundamental parameter for neutralizing a synthetic gastric juice. Neutralization tests indicate that doses as small as 150-200 mg of as-synthesized hydrocalumite increase the $\mathrm{pH}$ to normal acidity conditions of the stomach juice.

\section{Acknowledgement}

Authors are grateful to CDCH-UC.

\section{References}

Beers M H and Berkow R 1999 The Merk manual (Madrid, España) 10th edn, p. 221

Campos M, Santamaría J, Mérida J, Moreno R, Alburquerque M, Bruque S, Rodríguez E, Jiménez A and Maireles P 2009 Energy Fuels 24979

Cota J, Ramírez E, Medina F, Sueiras J E, Layrac G and Tichit D 2010 Appl. Clay Sci. 20498

Domínguez M, Pérez-Bernal M, Ruano-Casero R, Barriga C, Rives V, Ferreira R, Carlos L and Rocha J 2011 Chem. Mater. 231993

Fordtran J S, Morawski S and Richardson Ch T 1973 New Engl. J. Med. 288923

Kok K -H, Lim T -T and Dong Z 2008 Water Res. 421343

Linares C F, Sánchez S, Urbina de Navarro C, Rodríguez K and Goldwasser M R 2005 Micro. Meso. Mater. 77215

López-Salinas E, Llanos Serrano M E, Cotés-Jácome M A and Schifter-Secora I 1996 J. Porous Mater. 2291

Malinowski S, Szczepanska S and Sloczynki J 1964 J. Catal. 767

Mora M, López M I, Jiménez-Sanchidrián C and Ruiz J R 2011 Solid State Sci. 13101

Palmer S, Frost R and Nguyen T 2009 Coord. Chem. Rev. 253 250

Rivera A, Rodríguez-Fuentes G and Altshuler E 1998 Micro. Meso. Mater. 2451

Rousselot I, Taviot-Guého C, Leroux F, Léone P, Palvadeau P and Besse J-P 2002 J. Solid. State. Chem. 167137

Vielle L, Rousselot I, Leroux F, Besse J and Taviot-Guého C 2003 Chem. Mater. 154361 